\title{
THE EFFECT OF GAME IN INCREASING STUDENTS' VOCABULARY AT SD INPRESS TINGGIMAE
}

\author{
Nurfaizah Sahib ${ }^{1}$ \\ ${ }^{1}$ Faculty of Teacher Training and Education, Bosowa University, \\ Makassar, Indonesia
}

\begin{abstract}
The objective of this research is to find out whether or not the game increase the Students' Vocabulary at SD Inpress Tinggimae. This research employed a pre-experimental design with involved pre-test and post-test. The sample of this research was 30 students and there are three technique of collecting data were pre-test, treatment, and posttest. The result of the students' mean score in pre-test and post-test show thatThe mean score of the students pre-test is 5.4 and mean score of the students post-test is 83.2. in other word, there was the effect of game in increasing students' vocabulary.at SD Inpress Tinggimae.
\end{abstract}

Key words: Effect, Game, Vocabulary

\section{INTRODUCTION}

English is an essential languange in the world of communication. English plays important role in any aspects of international life, it is widely used and learned in the worid. English is used as a medium of conveying knowledge as we found in the libraries where so many books are written in English, therefore, English is very useful language for learning various kinds of knowledge ,such as art, science history, philosophy, polities and tecnology ect.it seem the mastery of English cannot be separated from the development of human resources to be complete their daily life.

The perception and realization of this need are based on the nation wide. The good assumption mastery of the language will instrumentally function not only as the key to many doors to development and advantage in science and technologies but also as a medium of building up, strengthening and maintaining good relation with other countries in the world.

Vocabulary is one of the elements in four language skill, namely listening, speaking, reading, and writing. Without understanding vocabulary, the students will be finding some difficulties. Therefore, the students must have knowledge vocabulary because it can positively facilitate the students to use English effectively in their communication, in other words, it leads the students to use English well 
The students cannot express their communicative needs (ideas, emotion) to someone clearly because have lacking vocabulary. The students cannot communicate and grasp someone ideas that are transmitted to their, therefore vocabulary is regarded as the most essential aspect in English. It does not only influence oral form, peaking and listening but also written and reading. Obviously, vocabulary affects the four language skills as a keg to succeed in mastering in those skills.

One of the techniques which can be used in teaching English vocabulary is game. Teaching vocabulary by using game is good to improve students' vocabulary because the students can find new words. Besides that, game is activities which help the learner to remember the material, and game is enjoyable and fun activity for the students in learning English vocabulary

The writer expects that using game in learning process wiil became interesting and the students can receive the meaning of words in enjoyable situation. he writer is interested to take the title "The Effect of Game in Increasing the Students' Vocabulary at SD Inpress Tinggimae

\section{REVIEW OF LITERATURE VOCABULARY}

Everyone who wants to master language, they must learn a lot of vocabularies. It can lead to success of mastering the language skill such as speaking, and reading.

It is very crucial to know what vocabulary is, There are many definitions of vocabulary. Hornby, (1995:1331) states that vocabulary is a total number of words which (with rules combining them) makes up language, range of words know to or used by a person in trade, profession, etc.

Brown (1984) confirms that vocabulary consists of the words that it is used when you speak or write and the words that you understand when listen or read. Having a lot of vocabularies can help you to communicate effectively each other.

Obviously, the students should have a good dictionary, perhaps large and small ones. In other words, the dictionary is one of Media to help the learners to find out difficult words or to add the learners' Vocabulary in speaking English because nobody ever learns all of the words in the dictionary.. Memorizing vocabulary will make the students get the easy way to comprehend what the speakers delivered. It seems that, if the learners have more vocabulary, it will help the learners hi speaking English.

In addition, Urdang and Flexner, (1986:1473) state that; 'vocabulary is a list of works used by or know to a facular or group of person “. Gove, (1966:158) comments out vocabulary is a list of words and sometimes phrase usually arranged in alphabetical order and defined as dictionary glossary of lexical".

Each individual, vocabulary may be categorized as having four separates but largely overlapping components. These components indicate how vocabulary 
is processed and how it is used. Each of use has a receptive and a productive capacity and within each capacity we process and utilize both spoken and written language. Smith and Johnson, (1980:67) have categorized the processing and utilization of the students' vocabulary that we receive vocabulary both auditory (listening) and visual (reading) channel. We generate to produce language both orally (speaking) and through the medium of printing.

\section{TYPES OF VOCABULARY}

The figure indicates that receive vocabulary trough auditory (listening) and usual (reading). We generate or produce language but in orally (speaking) and trough the medium or printer (writing). We usually orally either know the meaning of a word or we do not, regardless of whether we hear it, speak it or write it, they now probably know and understanding ( listening and reading) more words than we use in our writing and speaking ( Smith and Jhonson in Mastura : 2000:21)

Harmer ( 1991: 159) points out two types of vocabulary namely active vocabulary and passive vocabulary.

a. Active vocabulary refers to the vocabulary that the students have been taught or have learned and which they are aspect to be able to use.

b. Passive vocabulary refers to the vocabulary that the students do not frequently use but can be recognized and understood the meaning both in the textual contexts.

c. Oral vocabulary consists of word which are actively used in speech. The significant character of oral vocabulary is that it is actively but the used speaker in rehearsed situation.

d. Writing vocabulary consist of words which are actively used in writing since it is not order the constant of time. It may have substantially wider range than the vocabulary of rehearsed speech.

e. Listening vocabulary is the stock of words to which one responds with the meaning and understanding in the speech of others.

f. Reading vocabulary is the stock of words that one recognized when he sees them in print or writing.

The types of vocabularies above are important in increasing students' vocabulary by using game. Game is one of technique that we can use in teaching and can make the students fan I earning English.

\section{GAME}

Johnson (1981) stated that game-like activities have an obvious and important place in a theory of language learning based on the development of communicative competence.

Games are not activities mainly aimed to break the ice between the students or to kill time. Byrne in Ishak (2007-30) gives the definition to games as a form of play governed by rules. They should be enjoyed and fun. They are not 
just a diversion, area from routine activities, but a way of getting the learners to use the language in the course of the game.

Harmer (1992:101) states that games are a vital pail of a teacher's equipment, not only for the language they provide, but also for the therapeutic effect they have. Furthermore Mckeenhill, Haa L, (2003) in the New International Webster's Comprehensive Dictionary of the English Language, Games is "any contest undertaken for recreation or prizes, played according to rules, and depending on strength, skill, or luck to win".

Therefore, games involve many factors: competition, relaxation, and learning, in particular. The main focus of using game in class is to help the students learn a lot of vocabulary and have fun. However, the use of games in the classroom is equally important. Before playing games, the rules of the games are clearly explained and well understand by the students.

\section{CHARACTERISTIC OF GAMES}

Klauer (in Hadfield, 1984) indicates the characteristic of game as follows:

1. A game is governed by rules. To make simple activity into game, just give a couple of rules and that is all;

2. A game has objectives. One of the rules, and probably the main one, is the achievement of an objective. This objective can be something like making points for correctness or finishing an activity first;

3. A game needs less supervision from the teacher. It must be understood as linguistic supervision. Sometimes the game is conducted by the teacher who acts as judge, scorer, and/or referee.

\section{TYPES OF GAMES}

Klauer (in Hadfield, 1984) states that no all games are the same. More than one of categories listed here may sometimes apply to game.

a) Cooperative games.

In this type of game, the main action is centered in trying to reach the aim in cooperation. This type of game is excellent to encourage the shy students, so it requires the participation of all numbered of team, group or pair.

b) Competitive games.

In this type of game there is an overt competition between teams or sometimes of an individual against the rest of class. The competition may also be individual against other individuals. The object of this type of game is finishing or reaching the end before the other competitors making more points, surviving elimination, or avoiding penalties.

c) Communicative games.

The main objective of this type is getting the massage over to the other players and reacting appropriately to their massage. For example when the player give instruction, must be clear and the other player must follow them, and do exactly what it required to, the task usually practical. Like following instruction, drawing, persuading other players, etc. 
d) Code-control game.

This type of game requires the students produce correct language, like structure, spelling, pronunciation, etc. the production of correct language will make the player o the team wins point.

Based on the types of game above, the researcher assumes that games are able to help the students in learning, active, and enjoyable.

\section{METHODOLOGY}

The researcher applied pre-experimental method. The Population of this research was students at SD Inpress Tinggimae which consisted of 180 students. The sampling technique in this research was total sampling. The researcher chose sample by selecting the sample from Six grade at SD Inpress Tinggimae. The classes consisted of 30 students. The research data were collected using test, questionnaire and analyzed by means descriptive statistic through SPSS version 16 for windows program.

\section{FINDINGS}

\section{The Interpretation of the Result of Students' Achievement Test}

This section deals with the presentation and the elaboration of data about pretest and posttest, and the students' improvement in learning vocabulary before and after employing treatments. In addition, mean score of pretest, posttest, and and standard deviation of pretest and posttest as consideration in this research is also explored further. The detailed results are provided in the further presentation of the data.

The presentation of the data in this part is obtained through the vocabulary test interpretations. The interpretations are taken from mean score, standard deviation, frequency, and any other supporting source of statistical elements.

a. Scoring classification of the students' pretest

As being stated earlier that after tabulating and analyzing the students' scores into percentage, they were classified into six levels based on Puskur (2006:35). The following table is the students' pretest score and percentage.

Table 2. Rate percentage of the student's scores in pre-test

\begin{tabular}{|l|l|l|c|c|}
\hline \multirow{2}{*}{ No } & \multirow{2}{*}{ Category } & \multirow{2}{*}{ Range } & \multicolumn{2}{|c|}{ Pre-Test } \\
\cline { 4 - 5 } & & & Frequency & Percentage \\
\hline 1 & Ecellent & $90-100$ & 0 & $0 \%$ \\
\hline 2 & Good & $80-85$ & 2 & $6,7 \%$ \\
\hline 3 & Fair & $60-75$ & 15 & $50 \%$ \\
\hline 4 & Poor & $40-55$ & 7 & $23,3 \%$ \\
\hline 5 & Very poor & $5-35$ & 6 & $20 \%$ \\
\hline & & & 30 & $100 \%$ \\
\hline
\end{tabular}


Based on the table above, it Indicates that, no students $(0 \%)$ got excellent category, 2 students $(6,7 \%)$ got good category, 15 students $(50 \%)$ got fair category, 7 students $(23,7 \%)$ got poor category, and there were 6 students $(20 \%)$ got very poor category.

b. Scoring classification of the students' pretest

The scores of students' vocabulary achievement were classified into five levels. Those score then were tabulated and analyzed into percentage. The following table is the statistical summary of the students' posttest:

Table 3 Rate percentage of the student's scores of Post-test

\begin{tabular}{|l|l|l|c|c|}
\hline \multirow{2}{*}{ No } & \multirow{2}{*}{ Category } & \multirow{2}{*}{ Range } & \multicolumn{2}{|c|}{ Post-Test } \\
\cline { 4 - 5 } & & & Frequency & Percentages \\
\hline 1 & Excellent & $90-100$ & 7 & $23.3 \%$ \\
\hline 2 & Good & $80-85$ & 11 & $36.7 \%$ \\
\hline 3 & Fair & $60-75$ & 10 & $33 \%$ \\
\hline 4 & Poor & $40-55$ & 2 & $6,7 \%$ \\
\hline 5 & Very poor & $5-35$ & 0 & $0 \%$ \\
\hline & & & 30 & $100 \%$ \\
\hline
\end{tabular}

Based on the table above in post-test, there was 10 students (33\%) classified as exceleent, 7 students $(23.3 \%)$ classified as good, 11 students (36.7) classified as fair, 2 students $(6,7 \%)$ classified as poor, and no students classified as very poor.

c. The mean score and standard deviation in pre-test and post-test

A pre-test was given before the treatment to know the prior knowledge of the student. The result presented in the table as follows:

Table 4. The Means Score and Standard Deviation of Students' Pre-test and Post-test

\begin{tabular}{|c|c|c|}
\hline Test & Mean score & Standard deviation \\
\hline Pre-test & 57.4 & 21.7 \\
\hline Post-test & 83.2 & 16.2 \\
\hline
\end{tabular}

Table 4, showed the statistical summary of the student mean score in pretest and post-test. The mean score of the students pre-test is 57.4 and mean score of the students post-test is 83.2, in other word, there is there is the effect of game increasing students' vocabulary. 


\section{DISCUSSION}

Based on the data collected through games, as explained in the previous section showed that, the students' ability in vocabulary increased. It is supported by the result of frequency and rate percentage of students' pre-test and post-test. The result of this research also showed that the students could cooperate and play in game like guessing words, relation words and the game of sing a song with gesture to improve their vocabulary. They were not doubtful to talk about what they had known. The writer control and helped the students to overcome some difficulties if a student did not know to mention or did not know the vocabulary. In other words, using games train the students to increase vocabulary and it can be begun with mention some words relation their self, besides, they can use open dictionary before they mention or the game begun. Using this technique, the students were able to mention a lot of vocabulary without feeling shamed and increased the students' confidence and enjoyed or fun in learning English particularly in vocabulary. In other word, There are many advantages of using games; Games can lower anxiety, games can give motivation to the students and they can give more opportunity to the shy students to express their opinion and feeling, game also enable learners to acquire new experiences with a foreign language, the class can be relax which is created by using games, students remember things faster and better; game can be one of the good ways to add our vocabularies. Therefore, it can be concluded that game can increase the students 'vocabulary at SD Inpress Tinggimae.

\section{CONCLUSION}

Based on finding and discussion above, the writer can be concluded that game give the significant effect in increasing the students' vocabulary at SD Inpress Tinggimae. The students are enjoy the game and they feel happy. They got a lot of vocabulary by this game.

\section{REFERENCE}

Ermayani.2006. Teaching English Vocabulary Using Real Objects to the Primary School Puplis. Makassar. Thesis FBM UNM . Unpublished

Gay. R.L. 2006. Educational Research, Competencies For Analysis and Application, Eight Education. Columbus, Ohio; Charfes.E. Merril Publishing.

Good, Charter V, 1995, Dictionary of Education, New York: Me. Graw-Hill Book Harmer, Jeremy.1983. The Practice of English Language Teaching. New York: Longman, Inc.

Hornby, A.S. 1995. fixford Advance: Learners' Dictionary of Current E. Oxford. Oxford Uni Press. 
Hadfield, Jill. 1984. Elementary Communication Games. London: Oxford University London: George G. Harrap Co Ltd.

Ishak, Nurjannah. 2007. The students' Interest in Learning English Vocabulary Using Scrabble Game. Unpublished Thesis. Graduate Program State University Makassar

Johnson, Keith and Morrow, Keith. 1981. Communication in the Classroom. Application and Methods for a communicative Approach. Hong Kong: Longman Group (FE) Ltd

Mckeenhill, Haa L, 2003. Webster New twentieth century dictionary: Second Edition. New York: Simon and Scholar Morgan.

Smit, Mastura (2000). Teaching Vocabulary. London: Heinemann Education Book.

Yunus Gunadi Adi Putra.2007. Improving Vocabulary through Close Procedure Technique. Makassar. Thesis FBS UNM. 